\title{
Analysis of geothermal energy as an alternative source for electricity in Colombia
}

\author{
Samuel S. Salazar ${ }^{1}$, Yecid Muñoz ${ }^{1}$ and Adalberto Ospino ${ }^{2^{*}}$ (B)
}

\section{${ }^{*}$ Correspondence:}

aospino8@cuc.edu.co

2 Department of Energy,

Universidad de la

Costa, Calle 58 \# 55-66,

Barranquilla 080002,

Colombia

Full list of author information

is available at the end of the

article

\begin{abstract}
Geothermal energy is the energy that is stored inside the earth and which may be used by man either directly (with no transformation) or to generate electricity by means of a geothermal power plant. This article estimates the participation of geothermal energy in Colombia's electricity market by the year 2025, based on a review of current installed capacity in the country; potential sources of geothermal energy for electric power generation; the existing regulatory framework for projects involving renewable sources, and the geothermal projects currently under development in the national territory. Demand for electricity in Colombia will continue to increase, which implies that new electric power generation projects must be undertaken in order to meet the country's demand. The conclusion is that geothermal energy is a good alternative to help achieve this objective. By 2025, geothermal sources are expected to generate at least $1400 \mathrm{GWh}$ of electric power per year, equivalent to 1.65\% of total electricity estimate demand in Colombia. If the full potential that has been assessed were exploited, generation capacity could reach up to $17,400 \mathrm{GWh}$ /year (equivalent to close to $20 \%$ of the country's demand) by 2025.
\end{abstract}

Keywords: Geothermal potential, Electric power demand, Geothermal power plant, Non-conventional power sources

\section{Background}

Heat is a form of energy, and geothermal energy is the heat that is stored inside the earth, which when transferred to the surface can be used by humans. Uses for geothermal energy range from its direct use with no transformation, to the generation of electricity using geothermal power plants. Even though a huge amount of thermal energy is stored inside the earth, only a fraction of it is usable for mankind (Marzolf 2014; Dickson and Fanelli 2013). Given that geothermal energy is a renewable resource, it may be considered a solution for the environmental and energy shortage issues the world currently faces (Muñoz et al. 2014).

There are certain regions that are attractive for the generation of geothermal electricity; these are generally thermally active areas in the crust of the earth, near the boundaries of the tectonic plates. Colombia is located on the Pacific Ring of Fire, which is a substantial advantage in terms of its potential for developing geothermal energy power plants, because in this area the natural gradient of temperature of the subsoil near the surface of the earth is abnormally high, due to the volcanic activity. Such conditions are

(c) The Author(s) 2017. This article is distributed under the terms of the Creative Commons Attribution 4.0 International License (http://creativecommons.org/licenses/by/4.0/), which permits unrestricted use, distribution, and reproduction in any medium, provided you give appropriate credit to the original author(s) and the source, provide a link to the Creative Commons license, and indicate if changes were made. 
considered favorable for the use of geothermal energy (Marzolf 2014; Mejía and Rayo 2014).

The implementation of geothermal power plants has become more widespread with many projects to be carried out, especially in countries such as Argentina, Austria, Australia, Bolivia, Canada, Costa Rica, Chile, China, Ecuador, Ethiopia, El Salvador, France, Guatemala, Italy, Indonesia, Japan, Kenya, Mexico, New Zealand, Nicaragua, Philippines, Taiwan, Thailand, and The United States; Fig. 1 shows the geothermal installed capacity in the world (Bertani 2016).

In Colombia, there is no geothermal development yet. Geological studies are being carried out by the Colombian Geological Survey in the Nevado del Ruiz, Tufiño-ChilesCerro Negro, Azufral, Paipa, and San Diego areas. The use of geothermal energy for the production of electricity has faced a number of obstacles, such as limited technical and scientific capabilities for the exploration and development of these resources, the large investments and high risks involved in exploration, and non-application of regulatory frameworks on the development and use of such resources by the entities responsible for promoting and managing such projects. These factors have led to very slow progress in the performance of pre-feasibility studies for the use of these resources (Bertani 2015; Marzolf 2014).

This article discusses the potential of geothermal energy as an alternative for electric power generation in Colombia, including a review of planned geothermal power plants in the Colombian territory, and an assessment of the prospective future participation of geothermal power in the country's electricity supply.

\section{Electric power generation in Colombia}

The bulk of electric power in Colombia is generated by hydro-electric plants. Table 1 shows the participation of each technology in the Colombian electric power market, indicating that hydro-electric power is predominant, with $69.97 \%$ of the total, followed by thermo-electric power (gas and coal), which combined account for $18.05 \%$ of the total.

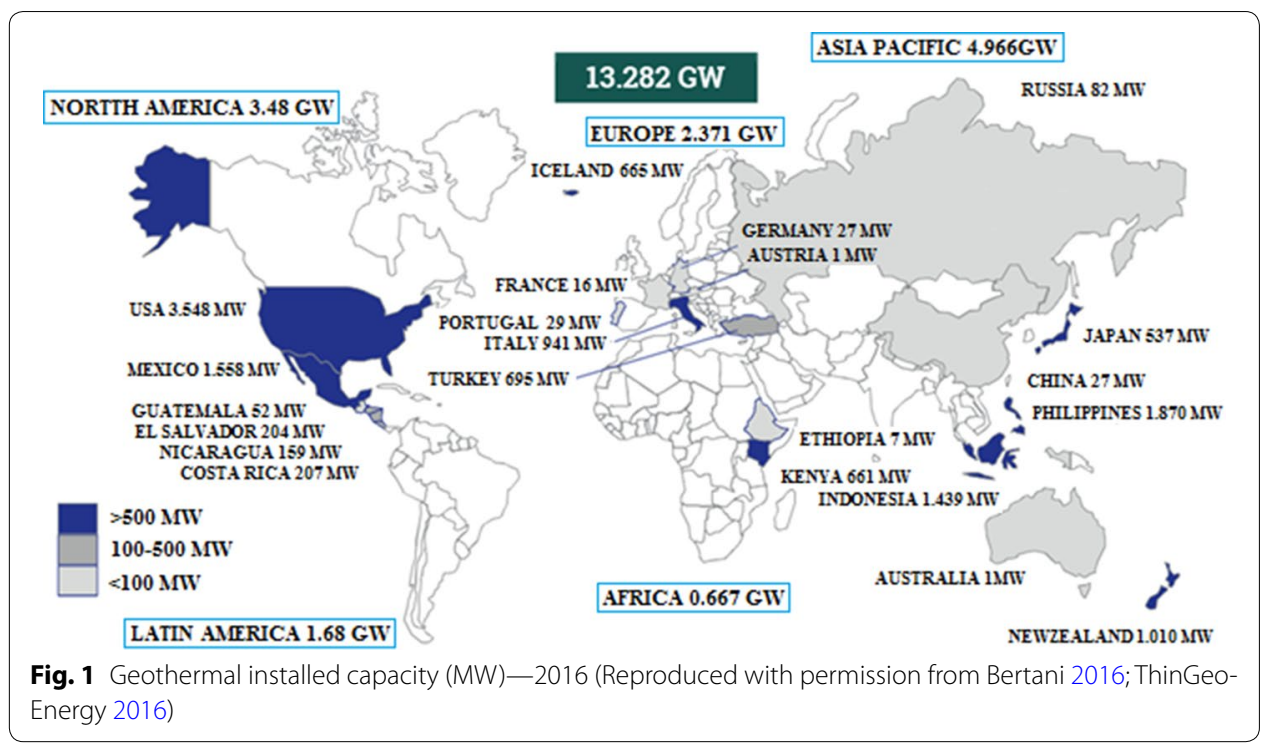


Table 1 Installed capacity by technology. Reproduced with permission from UPME (2015)

\begin{tabular}{lcc}
\hline Technology & Power (MW) & \% of total \\
\hline Hydro-electric & $11,500.50$ & 69.97 \\
Thermal-gas & 1619.50 & 9.85 \\
Thermal-coal & 1348.40 & 8.20 \\
Liquids & 1592.00 & 9.69 \\
Liquid gas & 264.00 & 1.61 \\
Biomass and wind & 111.60 & 0.68 \\
Total & $16,436.00$ & 100 \\
\hline
\end{tabular}

According to the monthly report on generation variables and the electricity market published by UPME, in December of 2015 the Colombian electric power system had installed capacity of 16,436 MW; electric power generation in Colombia in December, 2015 totaled $5703.88 \mathrm{GWh}$, a $3.13 \%$ increase compared to the same month the previous year, and the forecast for 2025 is $86,752 \mathrm{GWh} /$ year (UPME 2015, 2016).

\section{Geothermal potential in Colombia}

Colombia is an attractive country for the development of geothermal electric power plants because it is located on the Pacific Ring of Fire, and consequently there is volcanic activity along its Western and Central mountain ranges, as well as latent igneous activity in certain areas of the Eastern mountain range. The region has close to 15 active volcanoes and dozens of inactive ones. Figure 2 displays existing volcanoes worldwide, showing the existence of several of these in the Colombian territory (Corpoema 2010; IDEAM 2014).

Figure 3 shows the map of geothermal potential in Colombia in terms of the ranges of available temperatures at a depth of $3 \mathrm{~km}$ (Vargas et al. 2009). It shows that the most promising regions in terms of energy use are in the Andean region, where thermal anomalies are found with geothermal gradient values of up to $127^{\circ} \mathrm{C} / \mathrm{km}$. In these regions, hot fluids may be found at depths of between 500 and $1000 \mathrm{~m}$ that are capable of producing enough thermal energy for small-scale generation projects (Corpoema 2010).

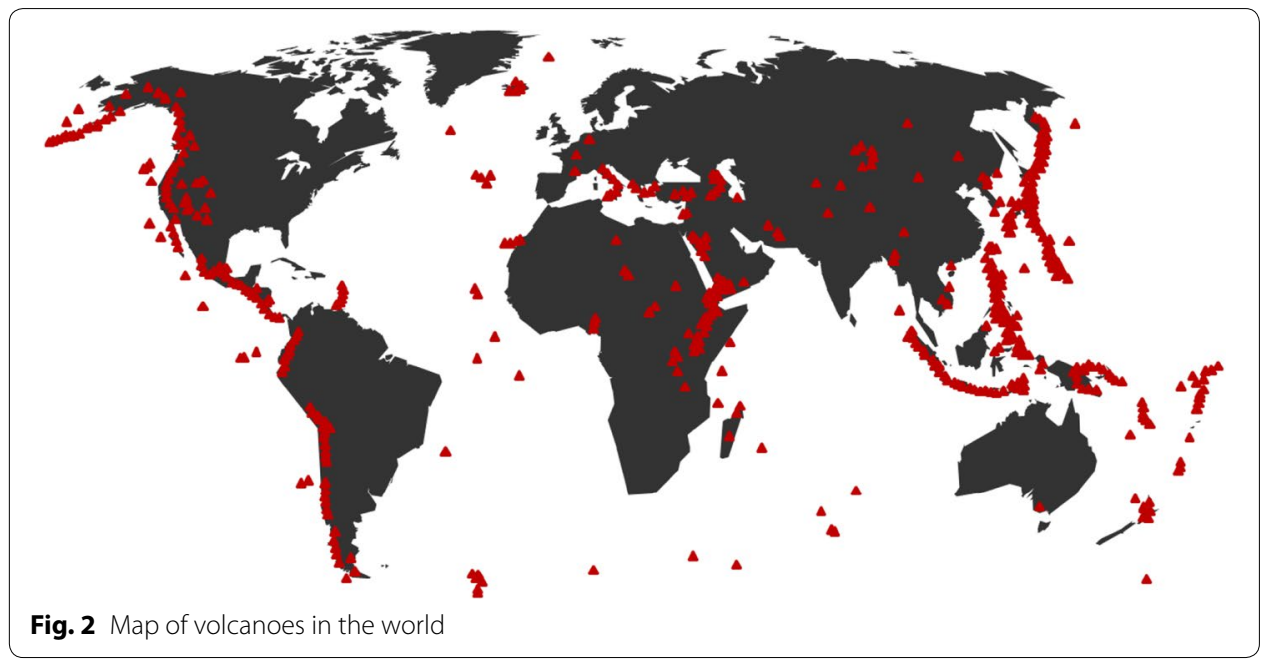




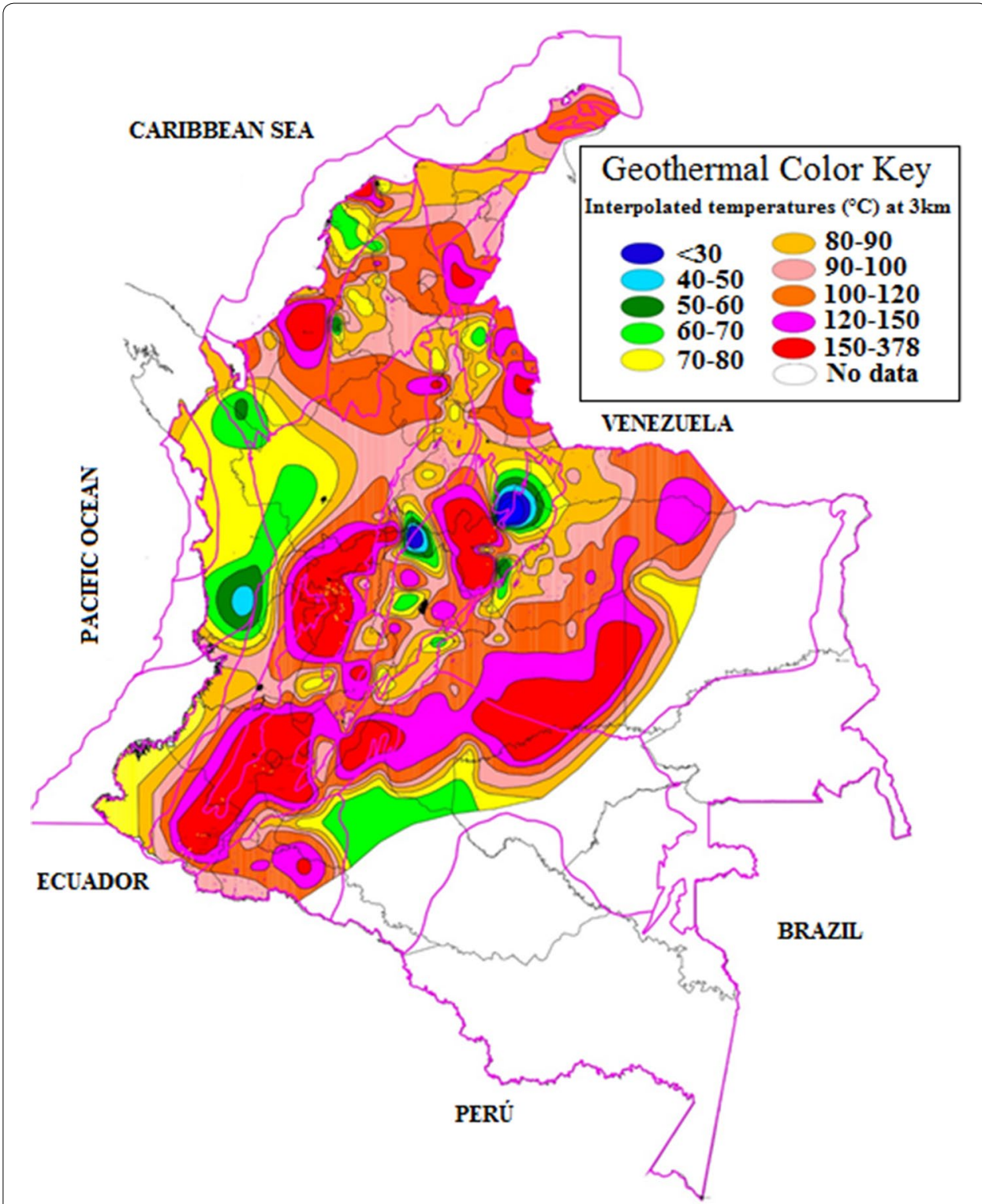

Fig. 3 Geothermal potential map [temperature in ${ }^{\circ} \mathrm{C}$ (at depth of $3 \mathrm{~km}$ )] (Reproduced with permission from Vargas et al. 2009)

In 1981 and 1982, a study was carried out by Latin American Energy Organization (OLADE) in agreement with ICEL (the Colombian Electric Power Institute) to survey geothermal resources in the Republic of Colombia. The objective of the project was to carry out a final selection of the most important areas of geothermal interest in the country. The study covered close to $100,000 \mathrm{~km}^{2}$ and included the central and western mountain ranges, which feature recent volcanic activity and the presence of high-temperature thermal springs on the surface, and the eastern mountain range with volcanic activity that is not as recent and the presence of high-temperature thermal springs. These studies showed that Colombia has areas of geothermal interest for installation of generation capacity of up to 1000 MW (Corpoema 2010; Porras and Gutierrez 2013). 
Colombia's geothermal potential was also estimated in 1999 by Liz Battocletti, at 2210 MW, which may be used to generate electric power; the study covered sites such as Santa Rosa de Cabal, the Ruiz Complex, Paipa, Azufral Volcano, Chiles, Cumbal, Cerro Negro, and Tufiño (Battocletti 1999).

\section{Regulations on the use of geothermal resources in Colombia}

A regulatory framework exists in Colombia on the use and exploration of geothermal resources, which covers aspects related to surveying, pre-feasibility and feasibility studies, and the field and plant development stage (construction and operation). This section will discuss some legal aspects regarding the use of geothermal resources in the country.

The objective of law 1715 of 2014 is to promote the development and use of non-conventional renewable energy (NCRE) sources and to incorporate them into the national electric energy system. Its aim is to establish the legal framework and instruments for the promotion and use of NCRE sources, and to promote investment, research and development of clean technologies, including by means of investment incentives. Geothermal energy is considered a non-conventional renewable energy source. Law 1715 designated CREG (Energy and Gas Assignment of Regulation) as the entity responsible for the technical regulation of this resource, the national government as the promoter of subsoil exploration and research to survey existing geothermal resources, and the Ministry of Mines and Energy as the body responsible for establishing the conditions for the participation of geothermal energy in the Colombian energy market, as well as the technical and quality requirements for the facilities that use such resources to generate electricity (UPME 2014).

Geothermal energy is considered a renewable natural resource that is owned and managed by the State, given that according to Decree-Law 2811 of 1974 all natural renewable resources belong to the nation. Management of such resources is assigned to a governmental entity (the Ministry of the Environment). In order to use and exploit geothermal resources, it is necessary to obtain legal permits, concessions, and environmental licenses (Marzolf 2014; Hurtado 1974).

The surveying, pre-feasibility, and feasibility studies that are required prior to building and operating a plant require some degree of legal security in terms of use of the resource, because they involve substantial capital investments and high levels of risk. It is therefore important to obtain the required permits before undertaking geothermal exploration. Decree 2811 of 1974 (the national code on natural and renewable resources and environmental protection) defines the permits that are required to begin exploration of natural resources with the objective of exploiting them. However, the duration of such permits is only 2 years, which is generally considered insufficient for geothermal exploration, which could take up to 5 years to cover all aspects (including pre-feasibility and feasibility studies). According to Law 2811 of 1974, a concession must be obtained in order to use and exploit geothermal sources: any individual, legal entity or partnership, public or private, that wishes to generate hydraulic, kinetic or electric energy must request a concession, and the concession for the use of water as a geothermal source is to be granted along with the concession for use of the geothermal resources. The environmental parameters the projects must fulfill are issued by the national government through the Ministry of the Environment and Sustainable Development (UPME 2014; Hurtado 1974). 
Even though geothermal energy is considered a clean, renewable, and environmentally viable technology for the production of electricity, it clearly has particularities that require designing and implementing environmental management measures in all stages of the process. For this reason, Colombian legislation establishes that obtaining an environmental permit is a mandatory requirement for the use of geothermal resources. Such permit would implicitly cover all other permits, authorizations and/or concessions required for the use, exploitation and/or effects on the renewable resources that would be required over the useful life of the project (Marzolf 2014; Hurtado 1974).

The Law on the Rational Use of Energy (Law 697 of 2001) promotes the rational and efficient use of energy and the use of alternative energy sources, among other provisions. Article 2 of said law establishes that the state has the duty of establishing the regulations required to make the use of renewable energy sources viable (Marzolf 2014).

\section{Geothermal electricity generation projects in Colombia}

In order to review the status of geothermal electricity generation projects in Colombia, first we must point out the stages of development for the commercial operation of a geothermal power plant. Figure 4 displays the phases and estimated times required to build a geothermal project. The process begins with a survey to recognize, identify, and select potential areas, including an analysis of environmental restrictions. It is followed by a pre-feasibility stage, which includes a series of studies (geological, geochemical, and geophysical), establishment of the thermal gradient, and development of the geothermal model. The pre-feasibility stage lasts approximately 2.5 years.

Afterwards, during the feasibility stage, exploratory drilling is performed, usually by means of wells at depths of $2-3 \mathrm{~km}$; during this stage the deposit is evaluated; technical and economic viability studies are prepared, and a plant design is developed. During the development stage, the production and re-injection wells are drilled and the pipelines and generation plant are installed, to finally reach commercial operation, as indicated in Fig. 4 (ISAGEN 2012). As mentioned in the section above, it is of utmost importance to secure the necessary permits for development in a timely way. Failure to do so could cause substantial delays in the development process.

To date, there are no geothermal power plants in operation in Colombia. Geological studies are being performed by the Colombian Geological Service at Nevado del Ruiz, Tufiño-Chiles-Cerro Negro, Azufral, Paipa, and the area of San Diego to establish the viability of developing projects in these areas (Alfaro 2015).

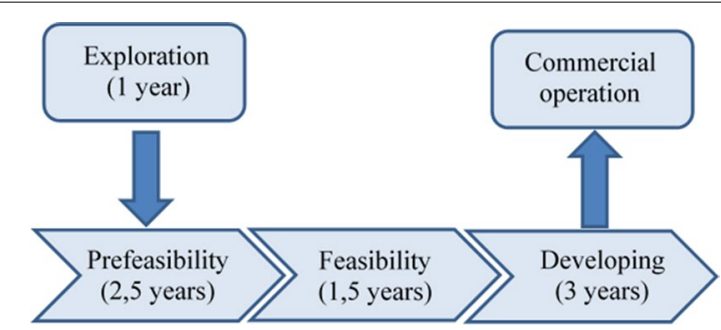

Fig. 4 Idealized scheme of the geothermal plant development stages (Reproduced with permission from ISAGEN 2012) 
Figure 5 displays the areas with geothermal potential in Colombia, where the green dots represent areas where exploration is currently being carried out by companies to generate electricity; the orange areas are in the pre-feasibility stage and are under study by government entities; the dark red areas have geothermal development potential and the yellow areas are those with substantial geothermal anomalies.

The geothermal projects in Colombia are displayed in Table 2, which indicates that the projects in the most advanced stage of development are the ones at Nevado del Ruiz and the bi-national project Chiles-Tufiño-Cerro Negro.

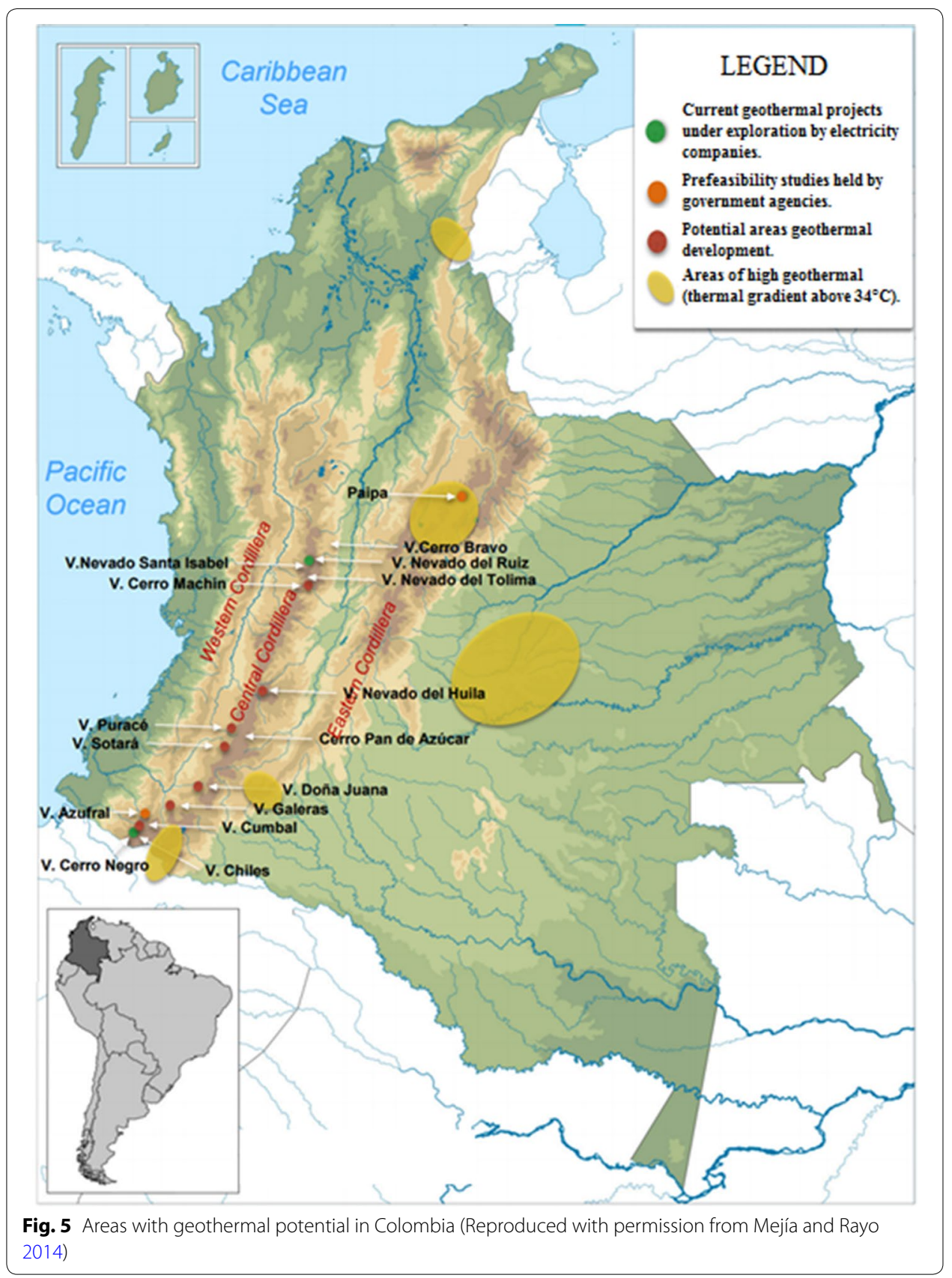


Table 2 Status of geothermal projects. Reproduced with permission from Mejía and Rayo (2014)

\begin{tabular}{lll}
\hline Project & Estimated capacity & Current status \\
\hline Nevado del Ruiz Volcanic Mountain & $50 \mathrm{MW}$ & Pre-feasibility studies complete \\
Bi-national project: Chiles-Tufiño-Cerro Negro & $138 \mathrm{MW}$ & Pre-feasibility studies in progress \\
Paipa & NA & Pre-feasibility studies SGC \\
Azufral volcano & NA & Pre-feasibility studies SGC \\
San Diego maar & NA & Pre-feasibility studies SGC \\
\hline
\end{tabular}

NA not available

The first to come to operation, which will become the first geothermal plant in the country, is being developed jointly by ISAGEN S.A. E.S.P., Toshiba Corporation, West Japan Engineering Consultants, Inc. (West JEC) and Schlumberger. This power plant will be in the municipality of Villa María, department of Caldas, with an installed capacity of $50 \mathrm{MW}$, and it is scheduled to begin commercial operation in 2020 (ISAGEN 2015).

The second is a bi-national project between Ecuador and Colombia, located on the border of both countries; its installed capacity will be $330 \mathrm{MW}$, of which $138 \mathrm{MW}$ will be on the Colombian side (Mejía and Rayo 2014; CELEC.EP. 2014), and according to the geothermal plant development stages, this power plant will begin commercial operation before 2025. Figure 6 shows the location of both power generation projects.

\section{Prospective view of geothermal energy in Colombia}

Table 3 displays a forecast of demand for electricity in the country for 2017-2030 prepared by the Mining \& Energy Planning Unit (UPME by its acronym in Spanish). Based on the forecast figure for 2025, an estimate was calculated on the participation of geothermal energy as a contributor to electricity supply in the country.

It is important to keep in mind that in addition to the areas where pre-feasibility studies for the use of this resource for generation of electricity are currently under way, as mentioned earlier, there are other areas that are suitable for electric power generation and where it might be worthwhile to promote geothermal projects to benefit the regions and diversify electricity supplies in Colombia.

By 2025, the Colombian electric power generation system will be producing $86,752 \mathrm{GWh}$ /year (UPME 2016). Taking into consideration the main geothermal projects in Colombia, and assuming that the geothermal plant at the Nevado del Ruiz Volcanic Mountain will come to operation in 2020, and assuming, based on normal development times for a geothermal power plant, that the bi-national project with Ecuador will be in operation by 2025 , the combined capacity of both plants would be 185 MW by 2025 , which adjusted by a generation factor of 0.9 , given that geothermal plants can operate with very few interruptions, these two plants would be generating $1400 \mathrm{GWh} /$ year. This would imply that geothermal energy would account for $1.6 \%$ of the total generation of the country's electric system by 2025, as indicated in Fig. 7 .

Pre-feasibility-stages studies are beginning for the geothermal areas of Paipa, Azufral Volcano, and San Diego maar. Preliminary conceptual models have been developed for the geothermal resources in these volcanic zones, leading to the characterization of the areas as being of great interest for geothermal power generation, presented to the World Geothermal Congress 2015. 


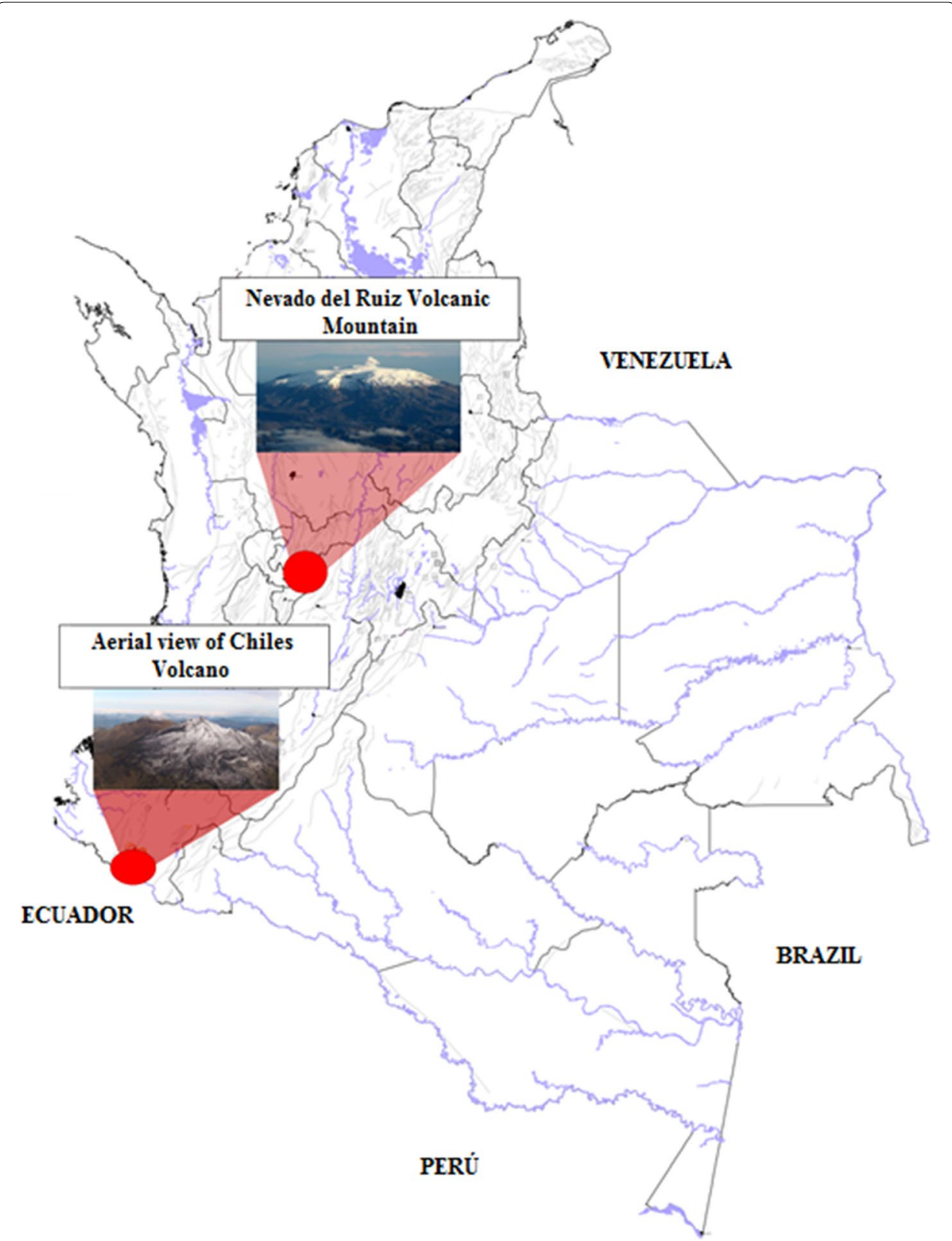

Fig. 6 Aerial view of Chiles Volcano and Nevado del Ruiz Volcanic Mountain (Reproduced with permission from SENCAR 2015; IG-EPN 2015; Vargas et al. 2009)

\section{Conclusions}

By 2025, with the projects at Nevado del Ruiz and Cerro Negro-Chiles-Tufiño on line, geothermal energy will account for $1.65 \%$ of electric power generation in the country, which although small compared to the percentages of other sources such as hydro-electric or thermo-electric plants, is nonetheless a contribution to the national grid.

Colombia is an attractive country in terms of geothermal energy because it has close to 15 active and numerous inactive volcanoes, and its location on the Pacific Fire Ring is an advantage in terms of making use of geothermal resources, because the thermal 
Table 3 Forecast of national demand for electric power. Reproduced with permission from UPME (2016)

\begin{tabular}{lll}
\hline Years & GWh & Growth (\%) \\
\hline 2017 & 69.748 & 4.0 \\
2018 & 73.230 & 5.0 \\
2019 & 75.341 & 2.9 \\
2020 & 77.387 & 2.7 \\
2021 & 79.164 & 2.3 \\
2022 & 80.923 & 2.2 \\
2023 & 82.704 & 2.2 \\
2024 & 84.648 & 2.4 \\
2025 & 86.752 & 2.5 \\
2026 & 88.930 & 2.5 \\
2027 & 91.243 & 2.6 \\
2028 & 93.659 & 2.6 \\
2029 & 96.166 & 2.7 \\
2030 & 98.809 & 2.7 \\
\hline
\end{tabular}

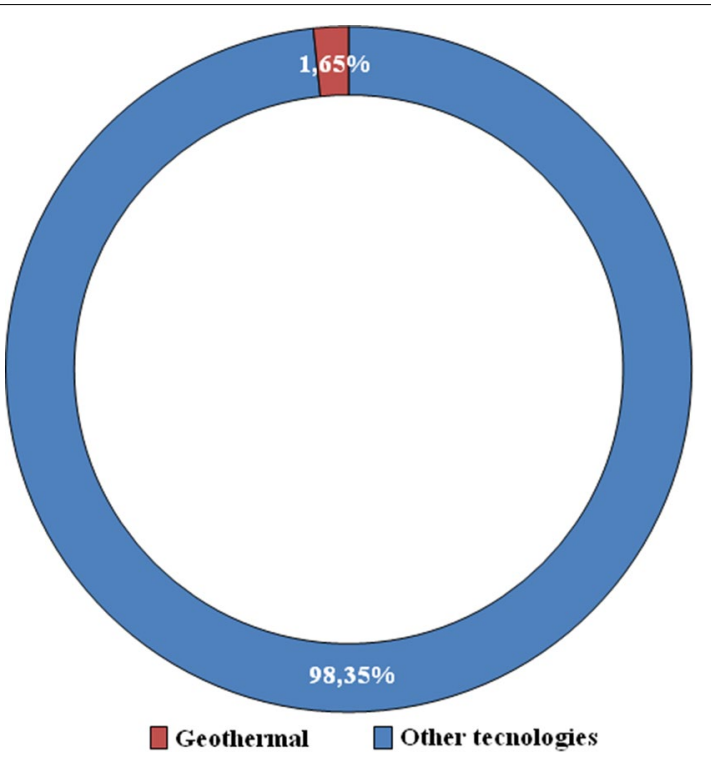

Fig. 7 Share of geothermal electricity in total electricity generation in Colombia by 2025

gradients are above normal. If the full potential that has been assessed were used, generation capacity could reach up to $17,400 \mathrm{GWh}$ /year, equivalent to close to $20 \%$ of the country's demand by 2025. Greater development of the country's geothermal resource base may be promoted by modifying the regulatory framework, adding incentives such as tax deductions and facilitating financing mechanisms, financial support or risk coverage. Developing the technical and scientific training of personnel in geothermal resources will also help in accelerating development.

The foreseen growth in demand in Colombia indicates that it is necessary to undertake new electricity generation projects to cover such demand, and geothermal energy is likely to play an important role, because in addition to being a renewable source of 
energy, it would help diversify the energy sources of the country's electric grid. With the support of legislation, incentives, and future projects (Azufral, Paipa, San Diego), geothermal electric power generation will increase its share of the country's generation system, which would also increase the reliability of the country's power grid.

\section{Authors' contributions}

The authors contributed to the discussions according to their respective areas of experience and knowledge for the interpretation of the data and the development of the basic concepts. SSS contributes to the revision of regulations for the use of geothermal energy in Colombia, electric power generation in Colombia and drafting of the manuscript. YM contributes to the potential and geothermal generation projects in Colombia and the drafting of the manuscript. AO contributes to the development of the perspective of geothermal energy in Colombia, makes a review of more relevant projects in geothermal generation around the world and drafting the manuscript with extensive contributions. All authors read and approved the final manuscript.

\section{Author details}

${ }^{1}$ Department of Engineering, Universidad Autónoma de Bucaramanga, Bucaramanga 680003, Colombia. ${ }^{2}$ Department of Energy, Universidad de la Costa, Calle 58 \# 55-66, Barranquilla 080002, Colombia.

\section{Acknowledgements}

Not applicable.

Competing interests

The authors declare that they have no competing interests.

\section{Availability of data and materials}

All information and data necessary to understand the results and conclusions drawn of the paper are in the text, tables, and figures or can be found in cited references.

\section{Consent for publication \\ Not applicable.}

Ethics approval and consent to participate

Not applicable.

Funding

Not applicable.

\section{Publisher's Note}

Springer Nature remains neutral with regard to jurisdictional claims in published maps and institutional affiliations.

Received: 9 May 2017 Accepted: 10 November 2017

Published online: 23 November 2017

\section{References}

Alfaro C. Improvement of perception of the geothermal energy as a potential source of electrical energy in Colombia. 2015. https://pangea.stanford.edu/ERE/db/WGC/papers/WGC/2015/01005.pdf. Accessed 15 Feb 2017.

Battocletti L. Geothermal Resources in Latin America \& the Caribbean. US Department of Energy, Office of Geothermal Technologies. 1999

Bertani R. Geothermal power generation in the World-2010-2014 Update Report. Proceedings World Geothermal Congress 2015 Melbourne, Australia, 19-25 April 2015, https://www.geothermal-energy.org/pdf/IGAstandard/ WGC/2015/01001.pdf. Accessed 19-25 Apr 2015.

Bertani R. Geothermal power generation in the world 2010-2014 update report. Geothermics. 2016;60:31-43.

CELEC.EP. Estado actual de la geotérmia en Ecuador y Colombia, Geothermal Energy Workshop, Corporación Eléctrica del Ecuador. 2014. http://alcuenet.eu/dms-files.php?action=doc\&id=686. Accessed 20 Mar 2017.

Corpoema. Formulación de un plan de desarrollo para las fuentes no convencionales de energía en Colombia (PDFNCE), Corporación para la Energía y el Medio Ambiente. 2010. http://www.upme.gov.co/Sigic/DocumentosF/Nol_1_Plan_ Desarrollo.pdf. Accessed 15 Feb 2017.

Dickson MH, Fanelli M. Geothermal energy: utilization and technology. United Kingdom: Routledge; 2013.

Hurtado J. Código Nacional de Recursos Naturales Renovables y de Protección al Medio Ambiente: Decreto 2811 de 1974. 1974. http://www.alcaldiabogota.gov.co/sisjur/normas/Norma1.jsp?i=1551. Accessed 16 Feb 2017.

IDEAM. Ecosistemas. Geomorfología de Colombia, Instituto de Hidrología, Meteorología y Estudios Ambientales. 2014. http://www.ideam.gov.co/web/ecosistemas/geomorfologia-colombia. Accessed 16 Feb 2017.

IG-EPN. Informe del volcán Chiles-Cerro Negro N.- 9, Instituto Geofísico de la Escuela Politécnica Nacional. 2015. http:// www.igepn.edu.ec/958-informe-del-volcan-chiles-cerro-negro-n-9. Accessed 20 Feb 2017.

ISAGEN. Desarrollo geotérmico en Colombia, WEC - COCME. II Jornada Técnica, Medellin; 2012.

ISAGEN. Relevant information. Toshiba and ISAGEN of Colombia sign a Memorandum of Understanding to evaluate the possibility of establishing a STRATEGIC ALLIANCE in which they will work together to develop the First Geothermal 
Power Plant in Colombia. 2015. https://www.isagen.com.co/comunicados/relevant-information-18-02-2015.pdf. Accessed 20 Feb 2017.

Marzolf N. Emprendimiento de la energía geotérmica en Colombia, Banco Interamericano del Desarrollo. ISAGEN. 2014 https://publications.iadb.org/bitstream/handle/11319/6558/Energia\%20Geotermica\%20Colombia\%207-1-14finalweb.pdf? sequence=1. Accessed 20 Apr 2017.

Mejía E, Rayo L. Geothermal development in Colombia. Short Course VI on Utilization of Low-and Medium-Enthalpy Geothermal Resources and Financial Aspects of Utilization, organized by UNU-GTP and LaGeo, in Santa Tecla, El Salvador. 2014. http://www.os.is/gogn/unu-gtp-sc/UNU-GTP-SC-18-07.pdf. Accessed 21 Mar 2017.

Muñoz Y, Guerrero J, Ospino A. Evaluation of a hybrid system of renewable electricity generation for a remote area of Colombia using homer software. Tecciencia. 2014;9(17):45-54. https://doi.org/10.18180/tecciencia.2014.17.6.

Porras D, Gutierrez F. Mecanismo de desarrollo limpio aplicado a la generación de energía eléctrica, con la utilización de energía geotérmica de baja entalpía en campos de producción petrolera de Apiay, Suria y campo Castilla (departamento del Meta, Colombia) (Doctoral dissertation). 2013.

SENCAR. Amenaza del Volcán Nevado del Ruiz, Congreso de la república de Colombia. Servicio de Noticias Cámara de Representantes. 2015. http://www.camara.gov.co/portal2011/noticias-destacadas/254-destacados-abril/1784amenaza-del-volcan-nevado-del-ruiz. Accessed 20 Mar 2017.

ThinGeoEnergy. Piensa en Geotermia. 2016. http://www.piensageotermia.com/ turquia-pasa-kenia-e-islandia-en-el-ranking-mundial-de-energia-geotermica/.

UPME. Colombia: Ley 1715 de 2014, Regulación de la integración de las energías renovables no convencioanles al Sistema Energético Naciona. 2014. http://www.upme.gov.co/Normatividad/Nacional/2014/LEY_1715_2014.pdf. Accessed 21 Mar 2017.

UPME. Informe mensual de variables de generación y del mercado eléctrico colombiano - Diciembre de 2015, Subdirección de energía eléctrica - Grupo de generación, Unidad de Planeación Minero Energética. 2015. http://www.siel. gov.co/portals/0/generacion/2015/Seguimiento_Variables_Diciembre_2015.pdf. Accessed 21 Mar 2017.

UPME. Proyección de la demanda de energía eléctrica y potencia máxima en Colombia, Unidad de Planeación Minero Energética. 2016. http://www.siel.gov.co/siel/documentos/documentacion/Demanda/UPME_Proyeccion_ Demanda_Energia_Electrica_Octubre_2016_version2.0.pdf. Accessed 21 Mar 2017.

Vargas CA, Alfaro C, Briceño LA, Alvarado I, Quintero W. Mapa Geotérmico de Colombia, 2009. In: Proceedings of X Simposio Bolivariano Exploración Petrolera en Cuencas Subandinas, Cartagena; 2009.

\section{Submit your manuscript to a SpringerOpen ${ }^{\circ}$ journal and benefit from:}

- Convenient online submission

- Rigorous peer review

- Open access: articles freely available online

- High visibility within the field

Retaining the copyright to your article

Submit your next manuscript at $\boldsymbol{\Delta}$ springeropen.com 